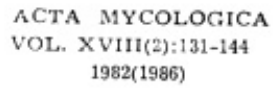

\title{
Studies on certain aspects of root surface fungi IV. Succession of fungi on Pennisetum typhoides in fertilized soils*
}

\author{
R. S. KANAUJIA** \\ Depa:tment of Botany, University of Gorakhpur, Gorakhpur (U.P.), India
}

Kanaujia R. S.: Studies on certain aspects of root surface fungi. IV. Succession of fungi on Pennisetum typhoides in fertilized soils, Acta Mycol. 18(2):131-144, 1982(1986).

The mycoflora and its succession on decomposing roots of $P$. typhoides of plots fertilized with urea, ammonium sulphate, superphosphate, organic manure, fresh leaves and twigs of Ipomoea fistulosa and irrigated has been investigated. Fungi were higher on fertilized plots, both a root surface and away from it (the control). Highest and lowest population were recorded soils fertilized with organic manure and $I$. fistulosa. The amino acids and sugars, cellulose, hemicellulose and lignin components of the roots from fertilized and control plots has been estimated and a correlation between mycoflora succession and the above components has been established.

\section{INTRODUCTION}

Waksman and Starkey (1924), Z a charias (1949), Ka ufmar and Williams (1964) and Kanaujia (1977) reported that the addition of various chemical fortilizers the soil inproved fungal growth. Ihe effect of fertilization on the rhizosphere mycoflora of various crop plant. also been studied (B a g y a r j and R a n g a s a m i 1967; M is hra 1971 a, b, 1972; M a urer and Baker 1965; $\mathrm{N}$ aim and Shaa$\mathrm{b}$ a $\mathrm{n}$ 1967). However, the effect of fertilization on the succession of fungi on recomposing underground plant parts is least understood ( $\mathrm{K}$ a-

* A part of Ph. D. Thesis, approved by University of Gorakhpur (U. P.) India.

** Present address: Department of Botany, K. S. Saket Post-Graduate College (of Awadh University), Faizabad (U. P.), India. 
n a u j i 1973) and this forms the bulk of the present study. In this study the effect of urea, ammonium sulphate, superphosphate, organic manure, fresh leaves and twigs of Ipomoea fistulosa and irrigation practice on the fungi and their succession on the decomposing Pennisetum typhoides (Burm f.) Stapt Hubb. roots has been examined.

\section{MATERIALS AND METHODS}

To investigate the effect of various fertilizers, organic manure, plant parts on the succession pattern of fungi on decomposing roots of. P. typhoides, the experimental plot where the crop was raised was ploughed over after remowing the above-ground plant parts in January 1971 and divided into seven equal parts. Urea (U), amonium sulphate (AS), supperphosphate (SP), organic manure (OM) and fresh leaves and twigs of Ipomoea fistulosa (IF) were added separately at the rate of $60 \mathrm{~kg} / \mathrm{acre}$ on January 1, 1971. One part of the plot was regularly irrigated fortnightly (IR) by a spraying method to bring its moisture content to of $25 \pm 1 \%$ and other was not treated (control). The first sampling of the roots and soil was made January 25, 1971 and subsequent ones were done once in a month till the total decomposition of the roots. The mycoflora associated with root ( $\mathrm{RS}$ - rhizosphere, RPC - cortical and RPS - stelar part of rhizoplane) and away from it (NR) was investigated by the method adopted by $\mathrm{Kanaujia}$ (1973). The amino acid and sugar contents of root on various sampling dates was determined by paper chromatography and calorimetry as suggested by Smith (1960) and Peach and Tracey (1955) and was expressed as $\mu \mathrm{g} / 2 \mathrm{~g}$ fresh roots. The cellulose, hemicellulose and lignin components were estimated on the basis of initial dry weight of roots (Wise et al. 1945). The $\mathrm{pH}$ and moisture content of the plots was determined every time using the methods described by $\mathrm{P}$ i p e r (1966).

\section{RESULTS}

Mycoflora of amended plots

Forty-three, 37, 36, 39, 42, 30 and 37 fungal species were isolated from U, AS, SP, OM, I, IF amended and control sets respectively. Eighteen species were commonly isolated from different root regions of ail the sets whereas 8 species were specifically present in NR of different sets (Table 1). Cladosporium epiphyllum (Pers.) Mart. and C. herbarum (Pers.) Link were quantitatively dominant in all the sets 
$\mathrm{T}$ a ble 1

Distribution of fungi of different taxonomic groups in non-rhizosphere (NR), rhizosphere (RS), and rhizoplane (RPC cortical and RPS steler) regions of fertilized plots

\begin{tabular}{|c|c|c|c|c|c|c|c|c|c|c|c|}
\hline \multirow[b]{3}{*}{ Amendment: } & & \multicolumn{9}{|c|}{ Taxonomic fungal groups } & \multirow[b]{3}{*}{$\begin{array}{c}\text { Total } \\
\text { No. of } \\
\text { spp. }\end{array}$} \\
\hline & & \multicolumn{2}{|c|}{$\begin{array}{l}\text { Phyco- } \\
\text { mycetes }\end{array}$} & \multirow{2}{*}{ 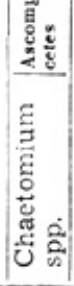 } & \multicolumn{5}{|c|}{ Deuteromycetes } & \multirow[b]{2}{*}{ 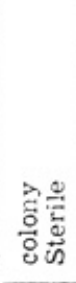 } & \\
\hline & & $\begin{array}{l}\text { 苛 } \\
\text { 营 } \\
\text { 号 }\end{array}$ & 䄱 & & 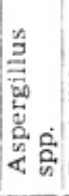 & 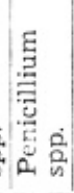 & 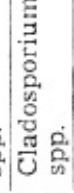 & 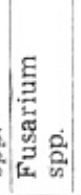 & 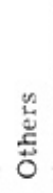 & & \\
\hline \multirow{4}{*}{ Urea } & NR & 2 & 3 & & 9 & 3 & 2 & 2 & 7 & 4 & 32 \\
\hline & RS & 2 & 2 & & 8 & 3 & 2 & 3 & 4 & 1 & 25 \\
\hline & $\mathrm{RPC}$ & & 2 & 1 & 5 & 2 & 2 & 2 & 2 & 2 & 18 \\
\hline & RPS & & 2 & & 3 & 1 & 2 & 2 & 1 & 2 & 13 \\
\hline \multirow{4}{*}{ Ammonium sulphate } & NR & 2 & 1 & & 9 & 4 & 2 & 2 & 3 & 2 & 25 \\
\hline & RS & 1 & 1 & & 9 & 2 & 2 & 1 & 4 & 1 & 21 \\
\hline & $\mathrm{RPC}$ & & 2 & & 4 & 2 & 2 & 3 & 2 & 2 & 17 \\
\hline & RPS & & 1 & & 2 & 1 & 2 & 2 & 1 & 3 & 12 \\
\hline \multirow{4}{*}{ Superphosphate } & NR & 2 & 2 & & 11 & 3 & 2 & 2 & 5 & 3 & 30 \\
\hline & RS & 1 & 3 & & 8 & 2 & 2 & 2 & 4 & 1 & 23 \\
\hline & $\mathrm{RPC}$ & & 2 & 1 & 3 & 1 & 2 & 1 & 3 & 1 & 14 \\
\hline & RPS & & 1 & & 3 & & 2 & 1 & 1 & 2 & 10 \\
\hline \multirow{4}{*}{ Organic Manure } & NR & 2 & 3 & & 10 & 2 & 3 & 2 & 4 & 4 & 30 \\
\hline & $\mathrm{RS}$ & 1 & 2 & & 10 & 2 & 2 & 2 & 4 & 2 & 25 \\
\hline & $\mathrm{RPC}$ & & 2 & & 5 & 2 & 2 & 2 & 3 & 2 & 18 \\
\hline & RPS & & 2 & & 4 & 1 & 2 & 1 & 1 & 2 & 13 \\
\hline \multirow{4}{*}{ Irrigated } & NR & 2 & 3 & 1 & 11 & 2 & 3 & 3 & 5 & 4 & 34 \\
\hline & RS & 2 & 3 & 1 & 9 & 1 & 2 & 3 & 4 & 2 & 27 \\
\hline & $\mathrm{RPC}$ & 1 & 2 & & G & & 2 & 3 & 3 & 2 & 19 \\
\hline & RPS & & 1 & & 4 & 1 & 2 & 3 & 3 & 2 & 16 \\
\hline \multirow{4}{*}{ Ipomoea fistulosa } & NR & 1 & 3 & & 6 & 3 & 3 & 1 & 4 & 2 & 23 \\
\hline & RS & 1 & 2 & & 5 & 2 & 2 & 2 & & 1 & 15 \\
\hline & RPC & & 2 & 1 & 2 & 1 & 2 & 1 & 1 & 2 & 12 \\
\hline & RPS & & 1 & 1 & 2 & 1 & 2 & 1 & 1 & 1 & 9 \\
\hline \multirow{4}{*}{ Control } & NR & 2 & 1 & 1 & 6 & 4 & 2 & 2 & 4 & 3 & 25 \\
\hline & $\mathrm{RS}$ & 1 & 3 & & 9 & 1 & 2 & 2 & 3 & 3 & 24 \\
\hline & $\mathrm{RPC}$ & & 2 & & 3 & 1 & 2 & 3 & 3 & 1 & 15 \\
\hline & RPS & & 1 & & 1 & 2 & 2 & 2 & 1 & 1 & 10 \\
\hline
\end{tabular}

during January to March. Other dominant fungi viz., Zygorhynchus heterogamus (Vuill.) Vuill. (AS, IF), M. hiemalis Wehm. (U, OM, I), 
Rhizэpus stolonifer (Ehr.) Vuill. (control), Aspergillus flavus Link (W, IF), A. niger v. Tiegh. (U, AS, SP, OM, IR and control), Penicillium chrysogenum Thom (SP, IF), Fusarium nivale (Fr.) Ces. (OM and control) and white sterile fungus - Wl (AS, SP and control) were obtoined from plots indicated in parentheses. Out of 59 fungi isolated in the present study deuteromycetes and among them Aspergilli were in majority in

Table 2

Distribution pattern of number of fungal species in ron-rhizosphere (NR), rhizosphere (RS) and rhizoplane (RPC cortical and RPS steller) regions of fertilized plots at different sampling periods

\begin{tabular}{|c|c|c|c|c|c|c|}
\hline \multirow[b]{2}{*}{ Amendments } & & \multicolumn{5}{|c|}{ Sampling period } \\
\hline & & Jan. & Febr. & March & April & May \\
\hline \multirow{4}{*}{ Urea } & NR & 13 & 12 & 13 & 14 & 7 \\
\hline & RS & 18 & 7 & 11 & 5 & 6 \\
\hline & $\mathrm{RPC}$ & $5,7^{*}$ & $5,8^{*}$ & $6,6^{*}$ & $4,3^{*}$ & $7,3^{*}$ \\
\hline & RPS & $4,4^{*}$ & $4,6^{*}$ & $4,4^{*}$ & $3,3^{*}$ & $5,2^{*}$ \\
\hline \multirow{4}{*}{ Ammonium sulphate } & NR & 7 & 8 & 13 & 13 & 7 \\
\hline & RS & 17 & 6 & 9 & 6 & \\
\hline & $\mathrm{RPC}$ & $13,8^{*}$ & $5,5^{*}$ & $5,8^{*}$ & $5,6^{*}$ & \\
\hline & RPS & $3,3^{*}$ & $4,4^{*}$ & $3,3^{*}$ & $4,3^{\circ}$ & \\
\hline \multirow{4}{*}{ Superphosphate } & NR & 6 & 11 & 15 & 19 & 7 \\
\hline & RS & 17 & 8 & 10 & 10 & \\
\hline & RPC & $4,5^{*}$ & $6,7^{*}$ & $6,3^{*}$ & $6,3^{*}$ & \\
\hline & RPS & 2 & $4,4^{*}$ & $3,4^{*}$ & $4,3^{*}$ & \\
\hline \multirow{4}{*}{ Organic Manure } & NR & 13 & 7 & 15 & 13 & 7 \\
\hline & RS & 18 & 6 & 8 & 9 & \\
\hline & RPC & $9,6^{*}$ & $5,6^{*}$ & $5,9^{*}$ & $6,3^{*}$ & \\
\hline & RPS & $2,5^{*}$ & $4,6^{*}$ & $5,6^{*}$ & $4,3^{*}$ & \\
\hline \multirow{4}{*}{ Irrigated } & $\mathrm{NR}$ & 16 & 16 & 19 & 19 & 13 \\
\hline & RS & 19 & 7 & 13 & 12 & \\
\hline & $\mathrm{RPC}$ & $7,6^{\circ}$ & $6,7^{*}$ & $7,6^{*}$ & $10,6^{*}$ & \\
\hline & RPS & $10,3^{*}$ & $5,7^{*}$ & $4,5^{*}$ & $6,6^{\circ}$ & \\
\hline \multirow{4}{*}{ Ipomoca fistulosa } & NR & 11 & 8 & 9 & 12 & 7 \\
\hline & RS & 11 & 6 & 6 & 6 & \\
\hline & RPC & $2,4^{*}$ & $5,4^{*}$ & $5,4^{*}$ & $3,3^{*}$ & \\
\hline & RPS & $1,4^{*}$ & $5,4^{*}$ & $2,3^{*}$ & $3,3^{*}$ & \\
\hline \multirow{4}{*}{ Control } & NR & 8 & 9 & 13 & 13 & 7 \\
\hline & RS & 16 & 7 & 10 & 11 & \\
\hline & $\mathrm{RPC}$ & $8,7^{*}$ & $6,6^{*}$ & $5,4^{*}$ & $5,3^{*}$ & \\
\hline & RPS & $3,3^{*}$ & $5,3^{*}$ & $3,4^{*}$ & $3,3^{*}$ & \\
\hline
\end{tabular}

- Represents the average number of coloniesfplate in the rhizoplane region. 
all the plots. The details are given in Table 1. The number of fungal species in RS, RPC and RPS regions of root and NR in amended plots varied differently, however, a gradual decrease to the number of fungal species from NR, RS, RPC, RPS regions was obtained in all the cases. Highest and lowest number of species was obtained in irrigated sets and those fertilized with Ipomoea fistulosa, respectively (Table 1). A similar trend of species on different sampling periods was observed (Table 2). Species in U, SP and OM stets were nearly equal and the same was true with AS and control sets (Table 1).

The population in NR region of all the sets was highest in January and decreased gradually onwards till the end. It was highest in the $\mathrm{OM}$ and the lowest in the IF set. Population at the root-surface exhibited varying trends. It was maximum in urea, superphosphate and control sets during February. In remaining cases maximum and minimum population was obtained during March and April respectively. In the set fertilized with IF the population was comparatively low during January and February, however, it increased considerably afterwards (Fig. 1). The differences in the fungal population on fertilized plots as compared with control were statistically significant (Table 3).

\section{T a ble 3}

Analysis of variance for fungal population caused due to the supplements and age of the decomposition

\begin{tabular}{|c|c|c|c|c|c|c|}
\hline $\begin{array}{l}\text { Variation } \\
\text { due to }\end{array}$ & SS & df & Variance & $\underset{\text { Calculated }}{\mathbf{F}}$ & Tabi & $\begin{array}{l}\text { F } \\
\text { ulated }\end{array}$ \\
\hline Amendments & 3179.04 & 6 & 529.84 & $3.00^{*}$ & 2.66 & 4.01 \\
\hline Age & 507.69 & 3 & 169.23 & 0.958 & 3.16 & 5.09 \\
\hline Fxp. error & 3179.04 & 18 & 176.61 & & & \\
\hline
\end{tabular}

- Significant at $1 \%$ level.

Amino acids and sugars in the roots on fertilized plots

A total of 15 amino acids (Table 4) was detected from the root extracts of all the sets. Alanine, arginine, giutamic acid, leucine, proline, threonine and valine were frequently present in the roots obtained from different plots whereas histidine and serine were present only in control and irrigated sets, respectively. Amino acids were nearly exhausted in April in the majority of sets (Table 4). The amount was generally highest in January and decreased insubsequent months (See 


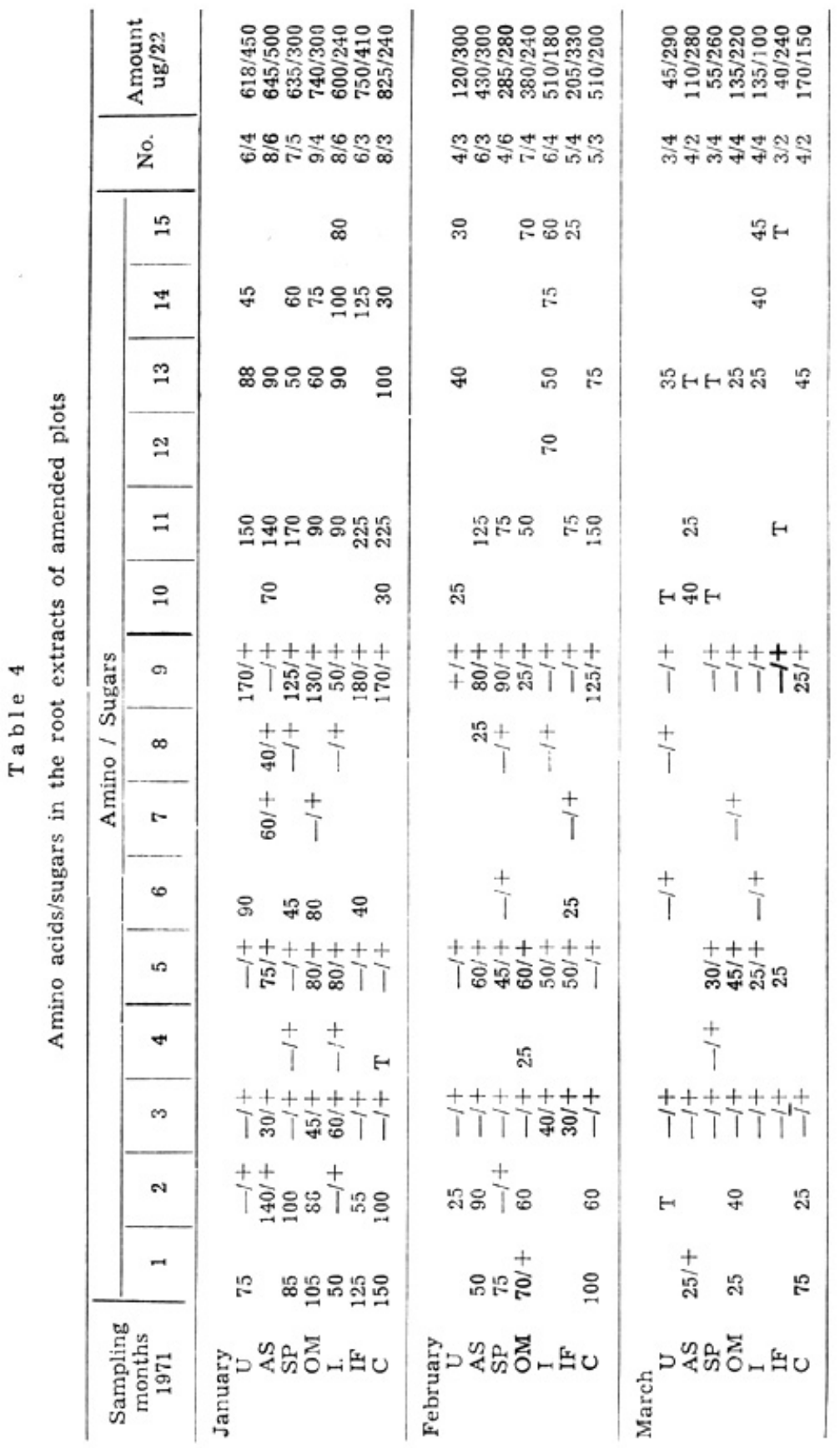




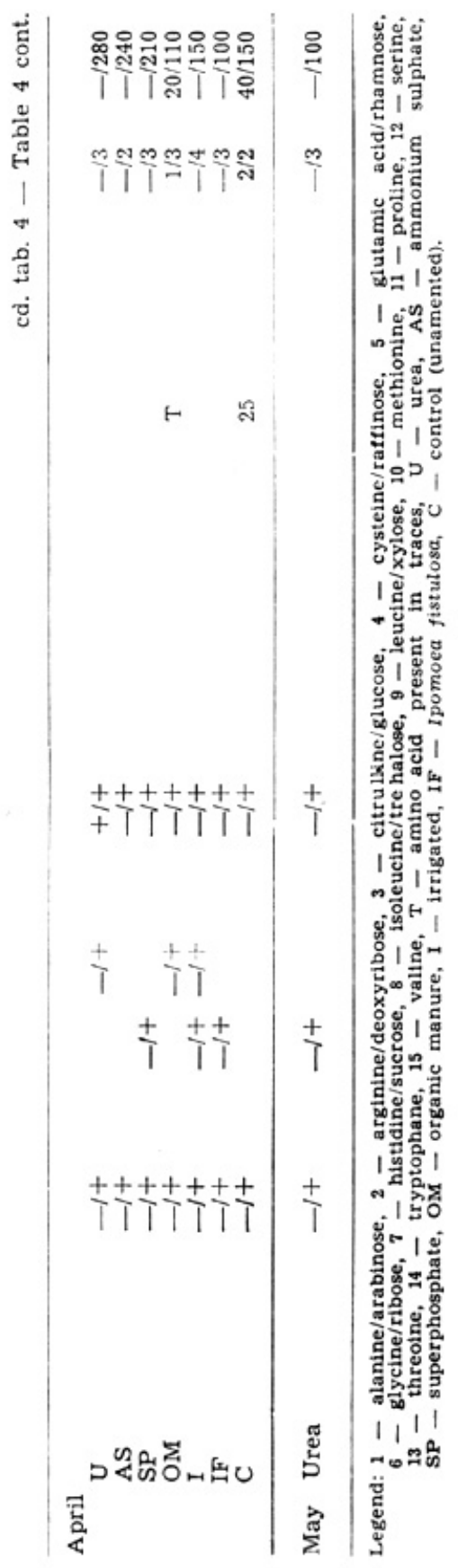




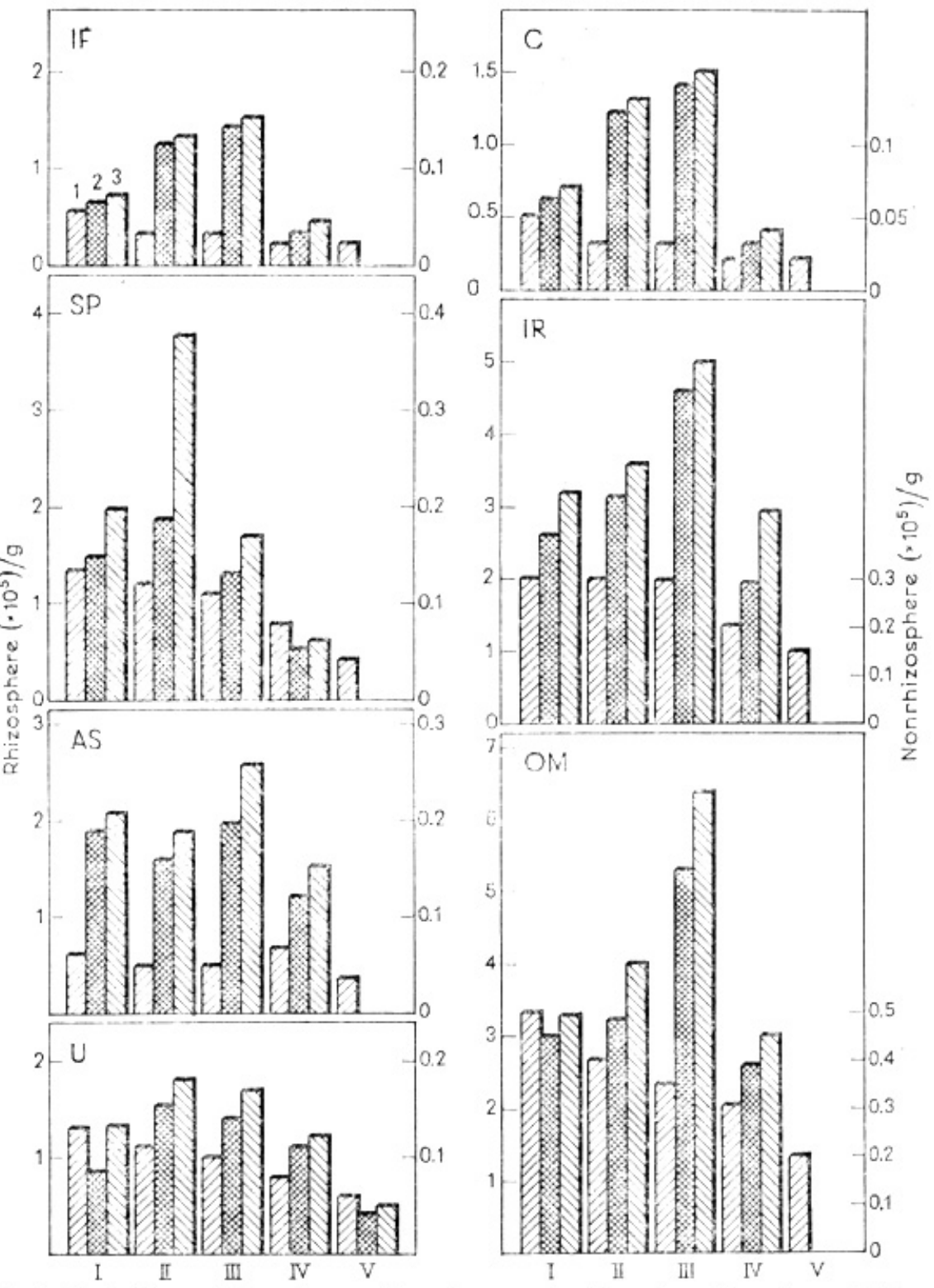

Fig. 1. Periodic variation in nonrhizosphere and rhizosphere fungal population of Pennisetum typhoides roots in fertilized plots in 1971

1 - nonrhizosphere fungal population $\left(\times 10^{5}\right) \mathrm{g}$ dry soil; 2 - rhizosphere fungal population $\left(\times 10^{5}\right) \mathrm{g}$ dry root; 3 - rhizosphere fungal population $\left(\times 10^{5}\right) \mathrm{g}$ dry soil

$I F$ - Ipomoea fistulosa; $S P$ - superphosphate; AS - ammonium sulphate; $U$ - urea; $C$ - control; IR - irregated; OM - organic manure 
details in Table 4). Nine sugars were obtained from roots-extracts of different plots. Glucose, and xylose were observed in all the sets during different stages of root decomposition. No regular pattern of distribu-
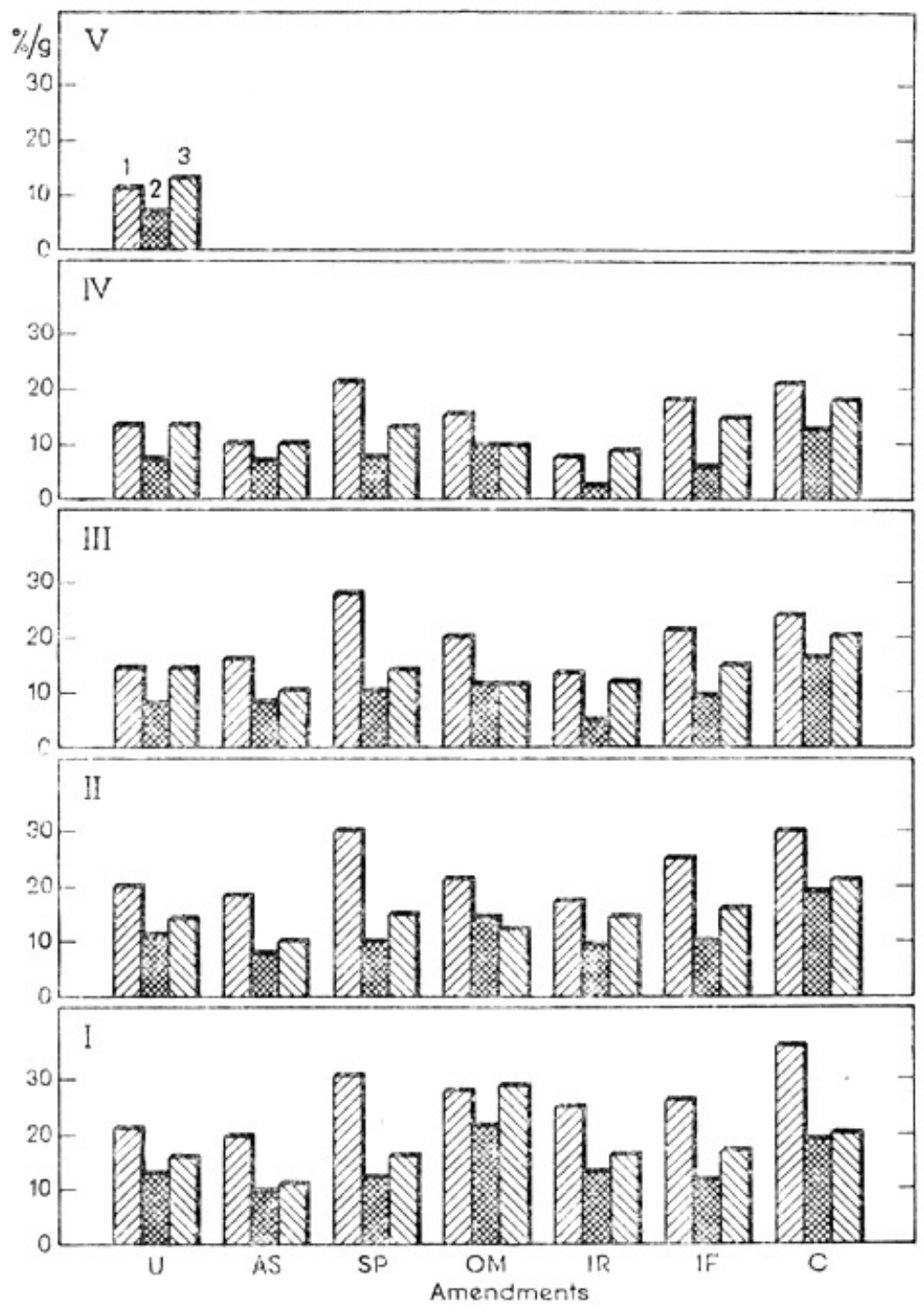

Fig. 2. Celluloses, hemicelluloses and lignins of Pennisetum typhoides roots decomposing in amended plots in 1971 (Amount initial dry WT of root)

$U$ - urea; $A S$ - ammonium sulphate; $S P$ - superphosphate; $O M$ - Organic manure; IR - irrigated; $I F$ - Ipomoea fistultna; $C$ - control 
tion of sugars in different sets was obtained. The amount of total sugars exhibited a trend similar to that for amino acids (Table 4).

Cellulose, hemicellulose and lignin components of roots

In all the sets the amount of the above three components was highest in January and then decreased gradually. Cellulose and hemicellulose decomposed more rapidly than lignin. Highest and lowest decomposition of the above components of the root was always recorded in irrigated and control sets respectively (Fig. 2).

Organic matter content and $\mathrm{pH}$ moisture content of fertilized plots

There existed no considerable differences in organic matter content and the $\mathrm{pH}$ of various plots except that $\mathrm{OMC}$ and $\mathrm{MC}$ was higher in the plots where organic matter content and water themselves were

Table 5

Organic matter content (OMC-\%), moisture content $(\mathrm{MC}-\%)$ and $\mathrm{pH}$ of fertilised plots

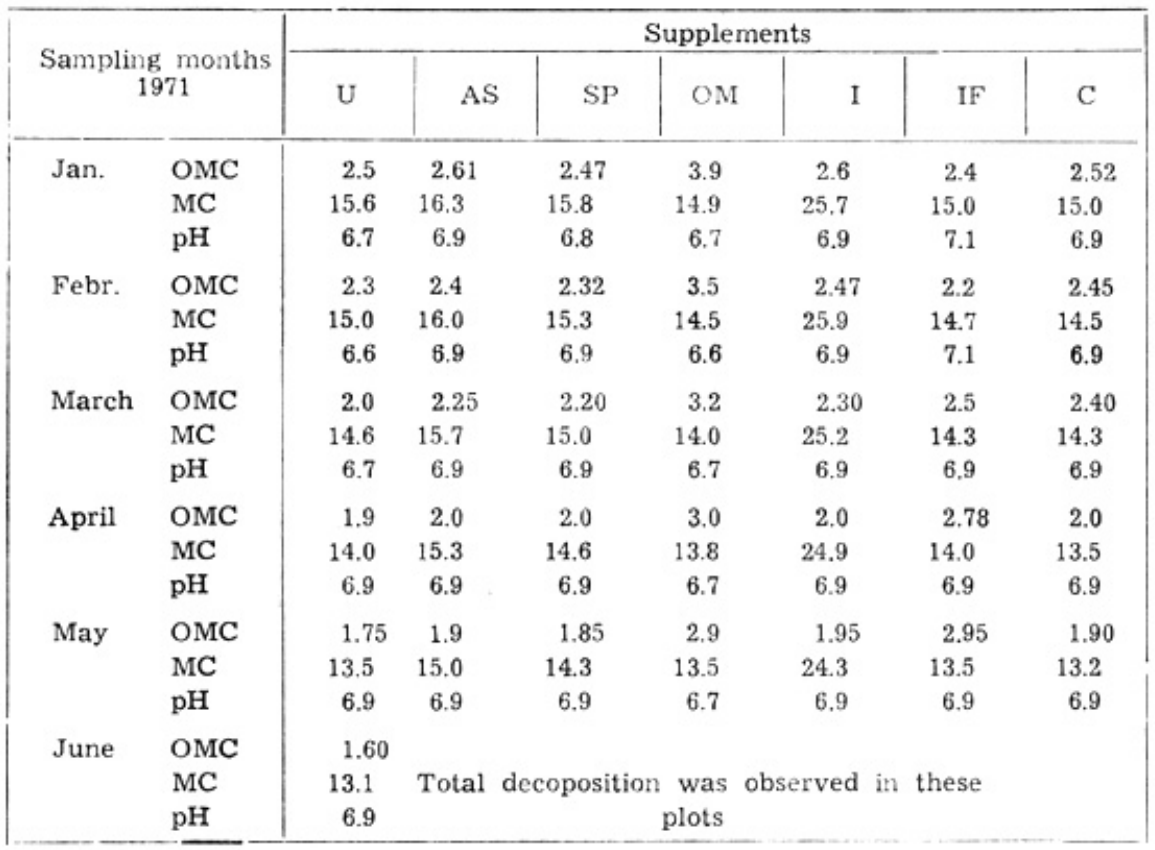


separately supplemented (Table 5). Except in the plot fertilized with urea plot, roots in other sets decomposed completely before 25th May and no data were obtained in these sets, however, in urea, these were exhausted during June.

\section{DISCUSSION}

The mycoflora of the plots containing different commercial fertilizers, organic manure and Ipomoea fistulosa varied differently. Irrigated and non-irrigated plots also showed considerable variation. The number of fungal species in all the fertilized sets except those supplemented with superphosphate and I. fistulosa was always greater than the control (Table 1). This is probably due to the availability of more nutrients in the supplemented soils.

W a k s m a n (1922) reported than plots receiving commercial fertilizers, applied separately or in combination, gave higher fungal counts than controls. Stimulation in fungal population by nitrate-nitrogen, phosphate and potassium has been reported by $\mathrm{Waksman}$ and $\mathrm{S}$ t a r k e y (1924). The beneticial effects of potassium chloride, calcium phosphate, ammonium sulphate and wood-ash-extract on soil mycoflora has been reported by $\mathrm{Z}$ a c harias (1949).

In the beginning the number of fungal species was generally higher in rhizosphere then away from it. On subsequent sampling dates, however, the pattern was reversed (Table 2). The greater number of species in this region may be ascribed to the increased level of nutrition. In rizosphere the fungal population was influenced both by decomposing root tissues as well as supplements. Recently M ishra (1971 a, b, 1972) and $\mathrm{K}$ a n a u jia (1973) have reported the beneficial effect of commercial fertilizers on rhizosphere mycoflora of Oryza sativa and P. typhoides. They observed that fungal species were more numerous in fertilized plots than in control ones.

Comparatively high fungal population in plots supplemented with organic manure and in irrigated at the root surface and away from it. Incereased nutritional status in the former and suitable moisture in the latter possibly accounted for higher fungal flora. Higher fungal counts in the organic matter rich soils has been emphasized by many workers (Dwivedi 1966; Kanaujia and Singh 1977; Mishra and K a n a ji a 1972 a, b, 1973).

A higher fungal population during the month of January from the root surface of $P$. typhoides which gradually decreased with ageing in the summer months may be attributed to the high amino acid and 
sugar content (Table 4). The breakdown of cellulose, hemicellulose and iignin (Fig. 2) supported the higher fungal population in the rhizosphere region. The lowest population in May in nearly all the sets was due to the high temperature and low moisture content of the soil.

A comparatively smaller population has been recorded in the plot supplemented witi, 1 . fistul ssa (Fig. 1) which is possibly due to the presence of some antifungal substance(s) in $I$. fistulosa. During early stages of decompositi n of the plant material the low fungal population may be due to the release of higher amounts of an antifungal substance (or substances) into the soil environment. At later stages, the concentration of antifungal substance(s) possibly decreased and the plant remains consequentiy harboured more fungi. The effect of added fresh plant material on soil mycoflora is porly understood and whatever little is known, is concerned with mycoflora of root diseased. B ha kuni et al. (1969) and $\mathrm{Dh}$ a $\mathrm{r}$ et al. (1968) while screening Indian plants for biological activity observed that Ipomoea illustris, I. leari, I. reptans and I. pestigridis possessed antifungal, antibacterial, antiviral, antiprotozoal and antifertility activities.

A greater number of fungal species were commonly associated with different plots and yet many were restricted to only one plot the former Fhenomenon may ke due to the similar edaphic and environmental conditions and common substrate available for colonization and the latter due to the variation in amendments and status and quality of nutrition, (Table 4).

There was no remarkable variation in the successional pattern of fungal species on the roots cf. $P$. typhoiles plyts supplemented in various ways. Few forms especially the species of Aspergillus and Fenicillium, few other Dzuteromycetes along with some sterile fungi were found to be associated with roots at all the stages. Many of them appeared as dominants which may be due to their wide range of nutri. tional acceptance and greater tolerance ( $\mathrm{Cochr}$ an e 1958).

The presence of Cladosporium species with high frequency during winter months may be due to the low temperature prevailing in this part of the country which is in accordance with our previous studies (Mishra and Kanaujia 1972, 1973). The dominance of sterile fungi during summer months may be due to the low moisture of the soil and high temperature. Dominance of other froms at various stages of root decomposition may be due to selective response to fertilizations and quality of the nutrition (M is hra $1971 \mathrm{a}, \mathrm{b}, 1972$ and $\mathrm{Kan}$ a u jia 1973). 
The $\mathrm{pH}$ of the soils (Table 5) in this study showed a poor correlation with soil fungal population and played a negligible role except for the fertilized with organic matter and for irrigated plots.

\section{Acknowledgements}

The author expresses his deep of sense of gratitude to Dr H. R. Mishra, now in Department of Botany, School of Life Sciences, N. E. Hill University, Shillong for his untired guidance and encouragement, to the Head, Department of Botany, University of Gorakhpur, for laboratory and library facilities and to my brother for financial assistance.

\section{REFERENCES}

Bagyaraj J. and Rangaswami G., 1967, Effect of fertilizers on the microflora of soil and the rhizosphere of ragi (Eleucine coracana). Mysore .I. Agric. Sci. 7: 176-186.

Bhakuni D. S., Dhar M. L., Dhar M. M., Dhawan B. N., and M ehrotra B. N. 1969, Screening of Indian plant for biological activity. II. Indian J. Exp. Biol. 7: 252-262.

Cochrane V. W., 1958, Physiological of fungi, London. Repr. Toppen Comp. Ltd., Tokyo, Japan, pp. 524.

Ehar M. L., Dhar M. M., Dhawan B. N., Mehrotra B. N., Ray C., 1968, Screening of Indian plants for biological activity I. Indian J. Exp. Biol, 6:232-247.

Garrett S. D., 1963, Soil fungi and soil fertility, Mac Millan Comp. New York, pp. 165.

Kanaujia R. S., 1973, Studies on succession of fungi on root-regions of Pennisetum typhoides (Burm f.) Stapf \& Hubb., Ph. D. Thesis. Univ. of Gorakhpur, India.

Kanaujia R. S., 1977, Studies on certain ecological aspects of soil fungi. VII. Technology 14: 136-139.

Kanaujia R. S., Singh C. S., 1977, Studies on certain ecological aspects of soil fungi. VI. Sydowia 30: 112-121.

Kaufman D. D., Williams L. E., 1964, Effect of mineral fertilization and soil reaction on soil fungi. Phytopath. 54: 134-139.

Maurer C. L., Baker R., 1965, Influence of glucose, cellulose and Inorganic nitrogen amendments on bean root rot. Phytopath. 55: 69-72.

Mishra R. R., 1971a, Effect of certain chemical fertilizers on the rhizosphere mycoflora of Oryza sativa. I. Mycopath. Mycol. Appl. 44: 167-176.

Mishra R. R., 1971a, Effect of certain chemical fertilizers on the rhizosphere mycoflora of Oryza sativa, Linn. II. Ibid, 45: 119-124. - 1972, ditto. III. ibid. 46: $97-102$.

Mishra R. R., Kanaujia R. S., 1972, Studies on certain ecological aspects of soil fungi. Trop. Ecol, 13: 5-11. - 1972b, ditto. III. Proc. Nat. Acad. Sci., India, 42B-II: 131-140. - 1973, ditto, II. Anl. Adafol. Agrobiol. 32: 21-34. 
$\mathrm{N}$ a i m M. S., Shaaban A. S., 1967, Relation of nitrogen fertilizers and manure to vascular Wilt of Egyptian cotton, caused by four Fusarium species and strains. Mycopath. appl., 3: 357-350.

Peach K., Trace M. V., 1955, Modern Methods of Plant Analysis. Springer Verl. Berlin.

Piper I., 1960, Amino acids and amides and related compounds; sugars and related compounds; Phenolic acids. [In:] Chromatographic and Electrophoretic Techniques, I, pp. 82-142; 246-260; 271-307). W. Heinemann Med. Books Ltd. London.

Waksman S. A., 1922, Microbial analysis of soil as index of soil fertility. III. Soil Sci. 12: 321-346.

Waksman S. A., Starkey R. L., 1924, Influence of organic matter upon development of fungi, actinomycetes and bacteria in soil. Soil Sci. 14: 373-378.

Wise L. E., Murphy M., D'A ddieco A. A., 1945, Chlorite, holocellulose, its fractionation and bearing on summative wood analysis and on the studies on the hemocelluloses. Paper Trade 122: 35-43.

$\mathrm{Zach}$ arias A. T., 1949, Microecology of cultivated fields of South India with special reference to the ocurrence and physiology of fusaria. $\mathrm{Ph}$. D. Thesis, Univ. Madras, India. 